УДК 655.027

\title{
ДОСЛІДЖЕННЯ ЕФЕКТИВНОСТІ ЗАСТОСУВАННЯ АДАПТИВНОГО МЕТОДА РАСТРУВАННЯ У ФЛЕКСОГРАФСЬКОМУ СПОСОБІ ДРУКУ
}

() В. П. Ткаченко, К.т.н., професор, О. В. Попов, К.т.н., Ю. О. Ястреб, магістр, ХНУРЕ, Харків, Україна

В работе исследована проблема повышения качества воспроизведения изображений в флексографской печати за счет применения на допечатной стадии алгоритма растрирования по технологии растровой печати высокой четкости. На основании проведенного исследования сделаны выводы относительно рациональности и эффективности применения данной технологии во флексографии.

This paper investigates the problem of improving the quality of imaging for flexo printing through the use of High Definition Halftone Printing screening algorithm on the Prepress. Based on the research conclusions about the rationality and effectiveness of using this technology in flexography are made.

\section{Постановка проблеми}

Сучасна флексографія представляє собою поліграфічну технологію, яка швидко розвивається та конкурує з іншими способами друку [1] не лише в сфері виготовлення етикетковопакувальної продукції, а й у друці газет. Це стало можливим завдяки розробкам нових формних пластин, вдосконаленню старих та впровадженню нових технологій, автоматизації контролю за друкарськими та додрукарськими процесами. Цей розвиток доповнюється подальшим прогресом в адаптації друкарських фарб до умов друку та зменшенням розмірів комірок растру анілоксових валів [2].

Головна відмінна риса флексографського друку - вико- ристання гнучких, в порівнянні 3 високим друком, відносно м'яких друкарських форм, які дозволили змінити процес подання фарби [1]. Через різноманіття використовуваних матеріалів та через малу твердість та пластичність друкуючих елементів флексографія встановлює дещо більш високі обмеження до допустимої товщини ліній та кеглю шрифтів, ніж офсет. Тим не менш, якщо дотримуватись цих обмежень, при виведенні векторних елементів зображення (таких як текст, лінії чи плашки) не порушується різкість границь та контраст 3 підкладкою. Дещо інакше виходить з растровою графікою.

у випадку використання будь-якого традиційного способу растрування (регулярно- 
го, стохастичного або гібридного) на якість репродукції впливають два параметра: плавність тонових переходів та графічна точність відтворення деталей, тому при виборі значення лініатури необхідно встановлювати компроміс між цими суперечливими вимогами. В цьому відношенні традиційні растрові системи не повністю використовують роздільну здатність формного та друкарського процесів [3].

В такій ситуації неминуче руйнування контурів та дрібних деталей зображення, що виникає вже в процесі репродукування зображення. У випадку флексографського друку до цих спотворень додаються ще й значне розтискування та дисторсія, які ще більше знижують якість зображення на відбитку.

Вирішити вказану проблему можна за допомогою адаптивного растрування, яке враховує інформаційний зміст конкретних ділянок зображення та їх безпосереднього оточення. Найбільш відомими серед таких методів $€$ алгоритми на основі дифузії помилки (зокрема, алгоритм Флойда-Стейнберга), які широко представлені в науковому плані. Але експериментальні дослідження показують, що жоден з цих алгоритмів не забезпечує повного позбавлення від характерних недоліків частотномодульованих растрів, в більшості випадків змінюється лише область градацій, в якій виникають небажані регулярні утворення [4].

Існує також метод (локальноадаптивний підхід, або техно- логія растрового друку високої чіткості - High Definition Halftone Printing, HDHP), розроблений на кафедрі Технології поліграфічного виробництва Північно-Західного інституту друку Санкт-Петербурзького державного університету технології та дизайну під керівництвом її завідуючого - професора Ю. В. Кузнєцова, який базується на об'єктивних фактах, зумовлених особливостями зорового сприйняття [5]. Ці факти стосуються вищевказаних вимог до плавності градієнтних переходів та точності відтворення деталей зображення: перша вимога більш актуальна на ділянках, де за сюжетом зображення тон змінюється плавно, а для дрібних деталей важливіша сама їх наявність та точність відтворення.

Ця технологія стосується лише растрової (піксельної) графіки, оскільки полягає у попередній обробці оригінальних TIFF-файлів, в ході якої 3 інформаційного змісту зображення виділяється контурна складова, яка адаптивно оброблюється й записується в окрему бітову карту зображення, при цьому растрові елементи, що формують маску, змінюються в залежності від сюжету зображення за додатковими растровими функціями, які генеруються на основі аналізу оточуючих ділянок оригіналу. Бітова карта фонової складової, яка записується в файл у форматі EPS разом з контурною частиною, раструється вже в растровому процесорі типо- 
графії з тими налаштуваннями, які в ній прийняті. Завдяки виділенню та відокремленню контурної складової зображення підвищується його різкість, ступінь деталізації та візуальний контраст (рис. 1).

\section{Мета роботи}

Дослідження ефективності адаптивного методу растрування HDHP у друці флексографським способом з метою підвищення якості відтворення растрової графіки.

\section{Методика дослідження}

Для оцінки ефективності застосування описаної технології при виготовленні продукції флексографським способом друку необхідно провести порівняльний аналіз якості тестсторінки $з$ використанням адаптивної обробки та без неї,

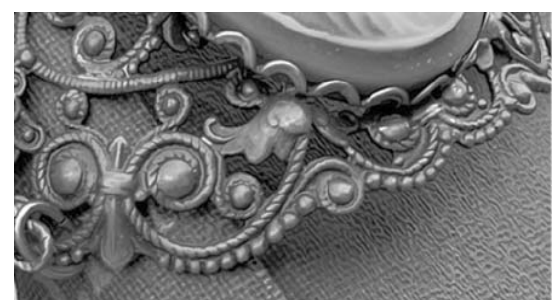

a)

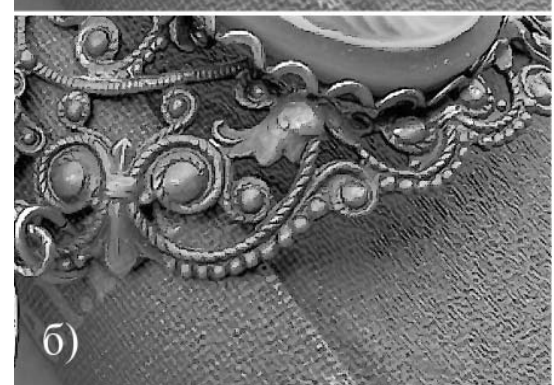

Рис. 1. Збільшене зображення вихідного (а) та обробленого адаптивним методом (б) зображення при цьому ключовими показниками якості будуть чіткість, різкість та контраст зображення. Розглянемо визначення для кожного з них.

Чіткість зображення - характеристика передачі дрібних деталей зображення (ОCT 29.40-2003).

Різкість зображення - характеристика, яка визначається шириною зони розмиття на границях деталей (ОСТ 29.402003).

Контраст зображення відношення яскравості найсвітлішої ділянки зображення до яскравості найтемнішої.

Тестова шкала для оцінки структурних характеристик растрової графіки (рис. 2) створена за допомогою програмного пакета Adobe Illustrator CS3, після чого проведена іiї растеризація в формат TIFF Grayscale з роздільною здатністю 240, 270, 300 dpi.

Перша шкала (1) складається 3 набору тест-об'єктів для оцінки чіткості та різкості зображення, які містять прямі та виворітні лінії товщиною від 100 до 400 мкм 3 кроком в 25 мкм для усіх значень кутів повороту растрової гратки, які використовуються у флексографії. Другий набір елементів (2) необхідний для оцінки якості передачі різкості границі «плашка-півтон». Третій набір (3) призначений для оцінки відтворення нерізкої контрастної границі з шириною зони розмиття 100550 мкм. Четвертий набір (4) оцінка передачі різкої границі різного контрасту (фон 20, 50, $80 \%$, об'єкти - 0...100 \% з кро-

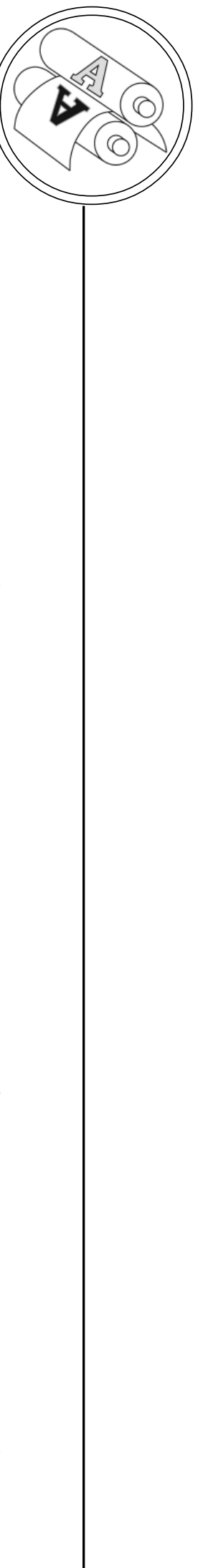




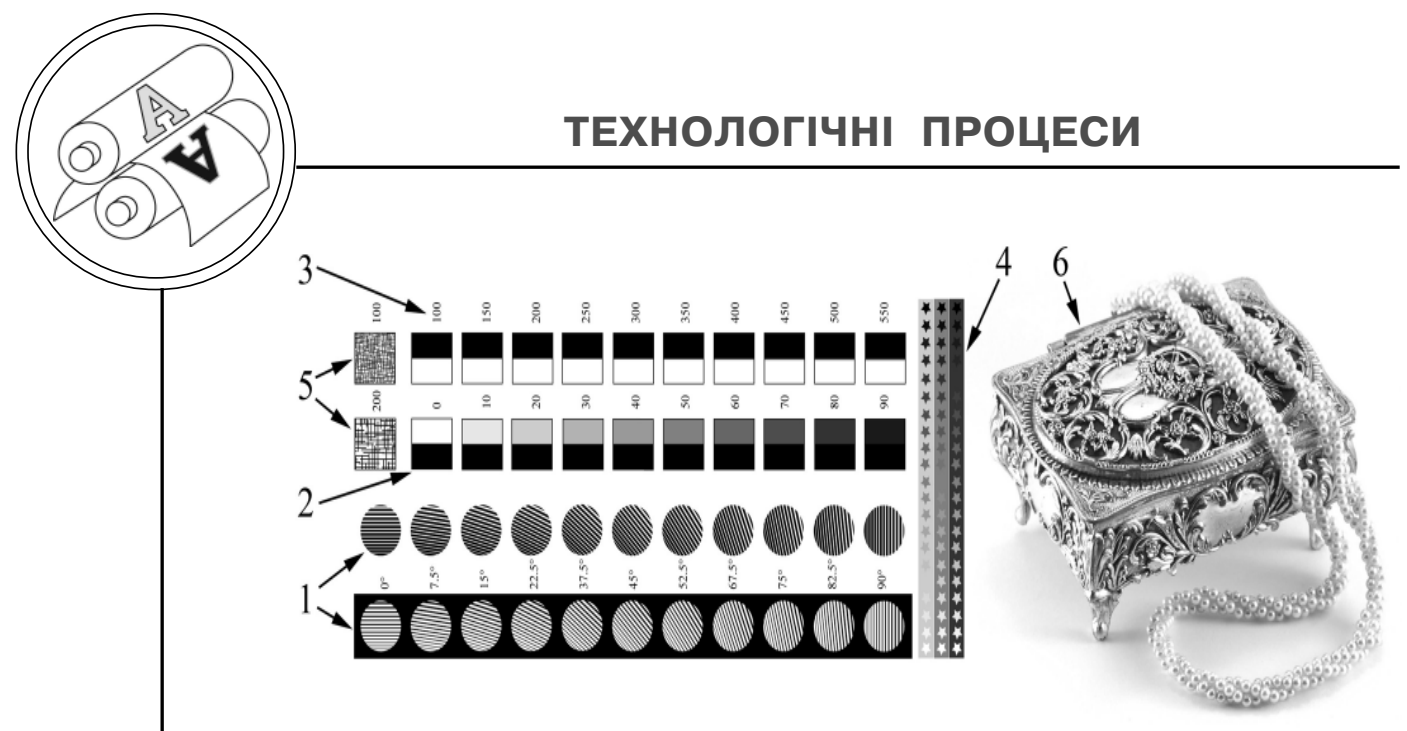

Рис. 2. Тестова шкала

ком $5 \%)$. У верхній частині тестсторінки розміщені контрольні елементи (5) з текстурою (товщина ліній 100 та 200 мкм). Для оцінки контрасту призначено растрове зображення (6) з високим ступенем деталізації.

Тестові зразки для кожного значення лініатури (119, 138, 149 Ірі відповідно) оброблені адаптивним методом HDHP. Растрування варіантів (регулярний та гібридний растр з попередньою обробкою та без неї) та гравірування кліше за технологією CtP проведені в лабораторії ПрАТ «НДІ Лазерних Технологій» (м. Харків). Відбитки з кліше отримані на обладнанні ТОВ «Поліграфічне підприємство «Фоліо+» (м. Харків).

За допомогою USB-мікроскопа Miview проведена мікрозйомка досліджуваних тестових шкал на відбитках, за допомогою інструменту Measure Tool програми Adobe Photoshop вимірювання параметрів елементів шкал.

\section{Результати проведеного} дослідження

На основі даних, отриманих при вимірюванні параметрів ліній набору (1), побудовано графік, що відображає залежність величини зони розмиття ліній від способу растрування та кута нахилу лінії відносно растрової гратки (рис. 3).

З отриманої залежності можна зробити такі висновки:

- ширина зони розмиття ліній (тобто ступінь руйнування контуру) різко зменшується з періодичністю р/4 (при куті нахилу растрової гратки відносно лінії, кратному $45^{\circ}$ );

- адаптивна обробка тесту дозволяє виводити на кліше та відбиток лінії з максимально рівним контуром, при цьому вона також дозволяє наблизити значення товщини відтворюваних ліній до номінальних (рис. 4), тобто має можливість адекватно відтворювати деталі та контури растрових зображень при флексографському друці. Якість відтворення деталей будь-яким 3 розглянутих методів підвищується зі збільшенням лініатури растра. 


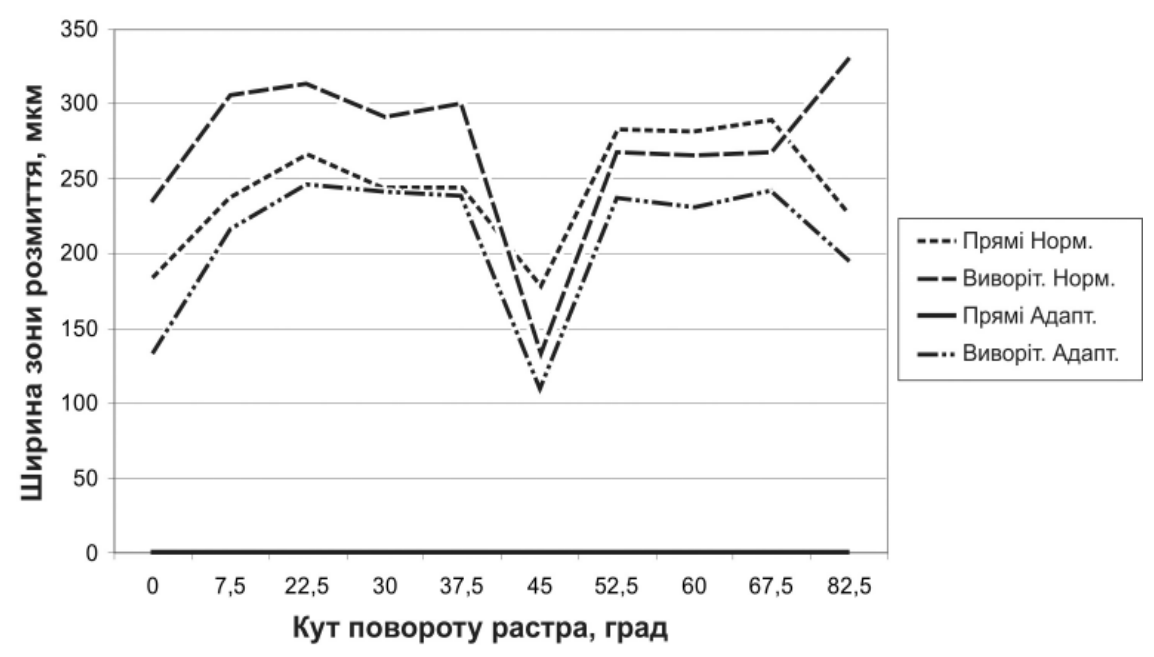

Рис. 3. Графік залежності середнього значення ширини зони розмиття від кута повороту растрової гратки для різних способів растрування, відбиток 119 Ipi

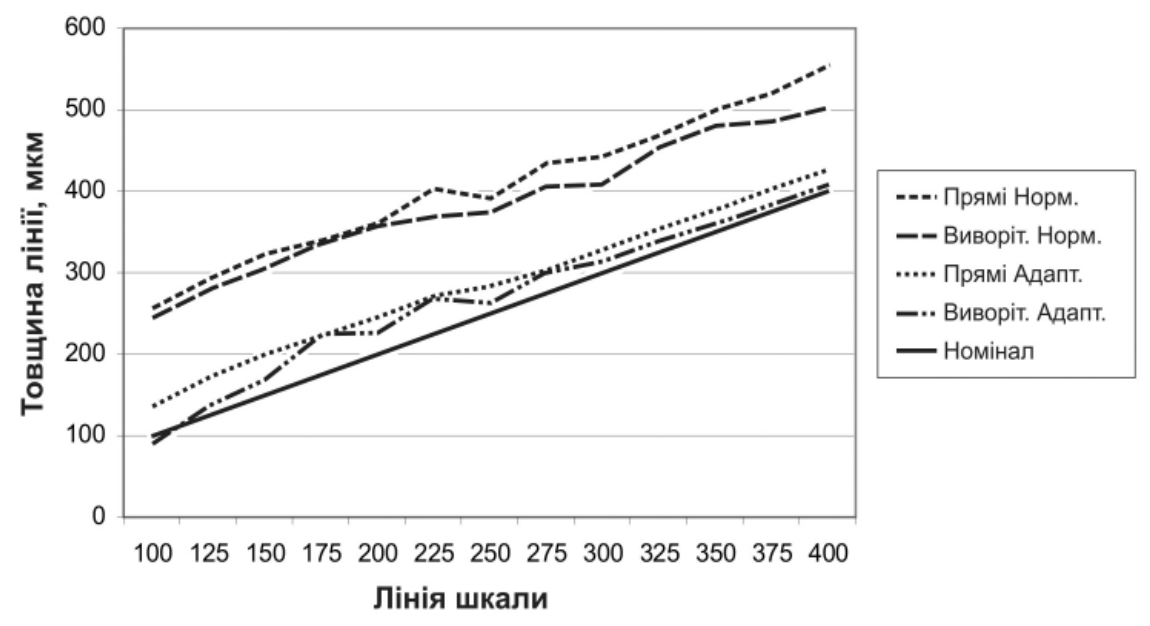

Рис. 4. Відповідність товщини лінії на відбитку номінальним значенням при різних способах растрування, 119 Ірі

Тим не менш, при раструванні адаптивно обробленого тестового файлу на деяких ділянках (шкала 1 для виворітних ліній (рис. 5, а), контрольні об'єкти 5 та 4 (рис. 5, б, в) виникають артефакти, які значно погіршують якість відтворення цих елементів зображення. 


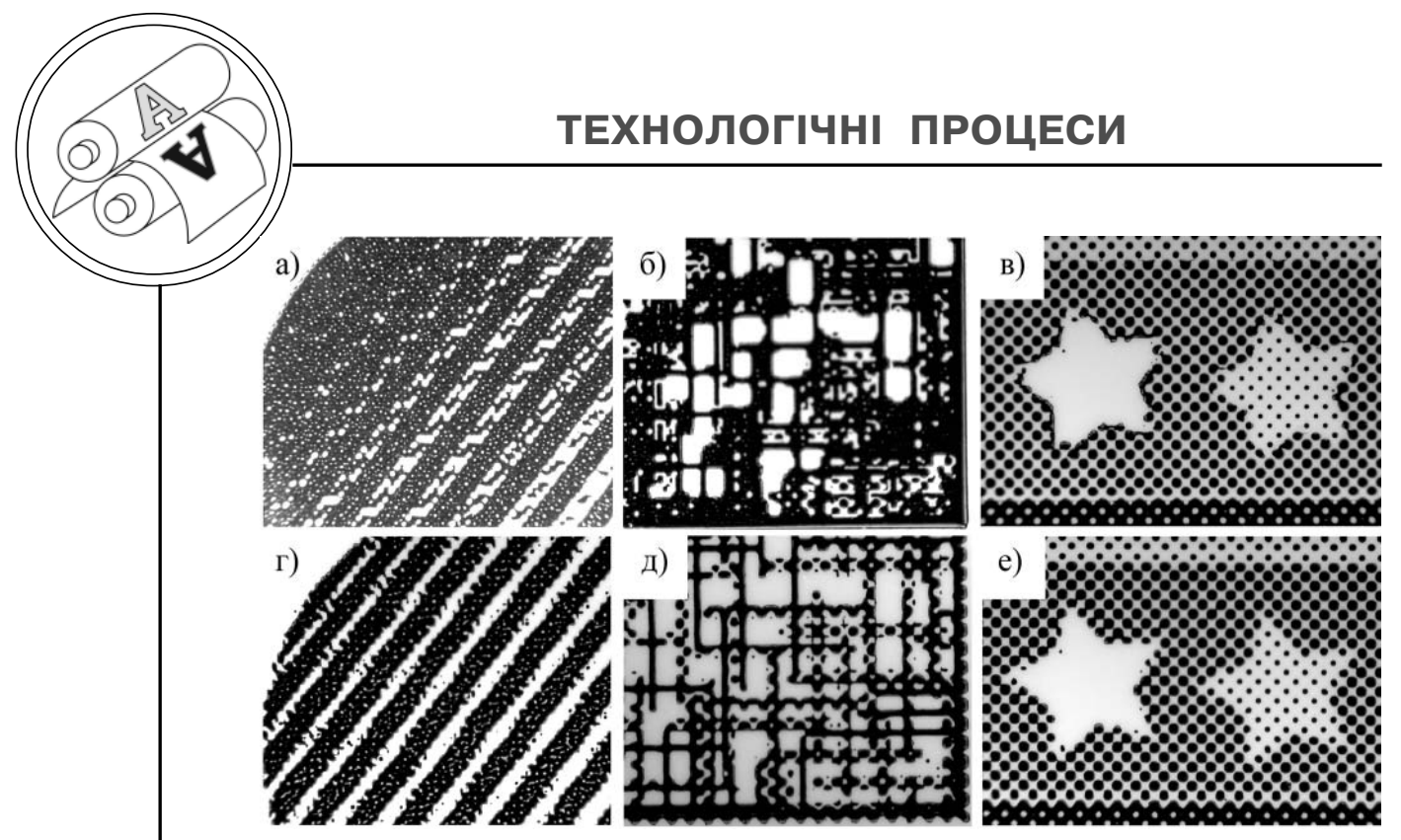

Рис. 5. Збільшене зображення виворітних ліній шкали 1 (а), контрольного елемента 5 с товщиною штрихів 100 мкм (б) та фрагмент шкали 4 (в) на відбитку з адаптивно обробленого тесту та відповідні ділянки для необробленого тесту (г, д, е)

Для проведення порівняння досліджуваних методів растрування на основі проведених вимірювань за методом аналізу ієрархій Сааті визначені вагові коефіцієнти переваги кожної 3 наявних альтернатив (традиційний регулярний та гібридний растри, адаптивний регулярний та гібридний растри) в межах локальних критеріїв якості $\left(\mathrm{f}_{1}-\right.$ чіткості, $\mathrm{f}_{2}$ - різкості та $\mathrm{f}_{3}-$ контрасту). Значення вагових коефіцієнтів за кожним з локальних критеріїв та узагальнена оцінка переваги А, для кожної 3 досліджуваних альтернатив у відсотковому вираженні занесені до табл.

За результатами оцінки ефективності за глобальним критерієм якості досліджувані методи растрування утворюють таку ієрархію (в межах кожної лініатури з невеликими відмінностями вагових коефіцієнтів):
- адаптивний гібридний растр;

- адаптивний регулярний растр;

- традиційний регулярний растр;

- традиційний гібридний растр.

\section{Висновки}

1. Досліджена можливість підвищення якості відтворення растрової графіки у флексографському способі друку за рахунок застосування адаптивного растрування.

2. Проведена оцінка якості передачі зображення різними растрами, на основі якої можна зробити висновок про те, що адаптивний метод растрування HDHP дає набагато кращі результати, ніж традиційний растр при використанні у флексографії. 
ТЕХНОЛОГІЧНІ ПРОЦЕСИ

Оцінка переваги альтернатив за глобальним показником якості

\begin{tabular}{|c|c|c|c|c|}
\hline \multirow{2}{*}{ Альтернатива } & \multicolumn{3}{|c|}{ Ваговий коефіцієнт в межах локального критерію } & \multirow{2}{*}{$\begin{array}{c}\text { Узагальнена } \\
\text { оцінка } \\
\text { альтернативи, \% }\end{array}$} \\
\hline & $\alpha_{\text {Aif } 1}$ & $\alpha_{\text {Aif2 }}$ & $\alpha_{\text {Aif3 }}$ & \\
\hline \multicolumn{5}{|c|}{ Лініатура 119 Ірі } \\
\hline Normal_Regular & 0,2086 & 0,1956 & 0,38 & 23,77 \\
\hline Normal_Hybridian & 0,2086 & 0,1956 & 0,14 & 18,97 \\
\hline Adaptive_Regular & 0,2913 & 0,3044 & 0,2 & 27,83 \\
\hline Adaptive_Hybridian & 0,2913 & 0,3044 & 0,28 & 29,43 \\
\hline \multicolumn{5}{|c|}{ Лініатура 138 Ірі } \\
\hline Normal_Regular & 0,19305 & 0,20945 & 0,38 & 23,70 \\
\hline Normal_Hybridian & 0,19305 & 0,20945 & 0,1 & 18,10 \\
\hline Adaptive_Regular & 0,30695 & 0,29055 & 0,24 & 28,70 \\
\hline Adaptive_Hybridian & 0,30695 & 0,29055 & 0,28 & 29,50 \\
\hline \multicolumn{5}{|c|}{ Лініатура 149 Ірі } \\
\hline Normal_Regular & 0,1942 & 0,2071 & 0,34 & 22,85 \\
\hline Normal_Hybridian & 0,1942 & 0,2071 & 0,1 & 18,05 \\
\hline Adaptive_Regular & 0,3058 & 0,2929 & 0,24 & 28,75 \\
\hline Adaptive_Hybridian & 0,3058 & 0,2929 & 0,32 & 30,35 \\
\hline
\end{tabular}

3. Виявлене в процесі роботи виникнення артефактів та руйнування пробільних елементів на адаптивно оброблено- му тесті потребує проведення додаткового дослідження причин їх появи перед впровадженням технології у виробництво.

1. Киппхан Г. Энциклопедия по печатным средствам информации. Технологии и способы производства [Текст] / Гельмут Киппхан; Пер. с нем. М. : МГУП, 2003. - 1280 с. 2. Ткаченко В. П. Оперативні та спеціальні види друку. Технологія, устаткування [Текст]: Навч. посібник / В. П. Ткаченко,, В. П. Манаков, А. В. Шевчук. - Х. : ХНУРЕ, 2005. - 336 с. 3. Кузнецов Ю. В. Основы подготовки иллюстраций к печати. Растрирование [Текст]: Учебное пособие для вузов/ Ю.В. Кузнецов. - М.: Изд-во МГУП «Мир книги». 1998.- 174 с. 4. Шовгенюк М. В. Аналіз способів цифрового растрування зображення з модульованою частотою [Текст]/ М. В. Шовгенюк, Н. С. Писанчин, Л. А. Дідух. - Львів : ФКС НАН України. - 2005. - 14 с. 5. Кузнецов Ю. В. Электронный гравер: прорабатываем детали. Новый способ растрирования/ Ю. В. Кузнецов// «Курсив». - 2005. - № 3 - www.kursiv.ru

$$
\text { Рецензент - В. П. Авраменко, }
$$
професор, ХНУРЕ

Надійшла до редакції 23.03.12 